\title{
Analysis of Optimum Butt Welded Joint for Mild Steel Components Using FEM (ANSYS)
}

\author{
Collins Eruogun Etin-osa*, Joseph Ifeanyi Achebo \\ Department of Production Engineering, University of Benin, Benin City, Nigeria \\ Email address: \\ etinosa.eruogun@uniben.edu (C. E. Etin-osa),josephachebo@yahoo.co.uk (J. I. Achebo) \\ ${ }^{*}$ Corresponding author
}

\section{To cite this article:}

Collins Eruogun Etin-osa, Joseph Ifeanyi Achebo. Analysis of Optimum Butt Welded Joint for Mild Steel Components Using FEM (ANSYS). Advances in Applied Sciences. Vol. 2, No. 6, 2017, pp. 100-109. doi: 10.11648/j.aas.20170206.12

Received: February 18, 2017; Accepted: May 19, 2017; Published: November 2, 2017

\begin{abstract}
Weld failure due to vibrations can be minimized if appropriate measure is implemented to ensure forced vibration is not equal to the natural frequency of the material. This research focuses on determining the optimum butt welded joint, by analyzing the various natural frequencies and mode shape response obtained from five different types of butt joints. In this study, modal analysis was carried out using ANSYS 14.5 on two mild steel plates of dimensions $250 \mathrm{~mm}$ by $175 \mathrm{~mm}$ by $25 \mathrm{~mm}$ welded together. Five different geometries of butt joints namely: single $\mathrm{V}$ groove butt weld, double $\mathrm{V}$ groove butt weld, single $\mathrm{U}$ groove butt weld, double $\mathrm{U}$ groove butt weld and square groove butt welded joints were examined. The natural frequencies and mode shape deformations obtained were compared with the natural frequency of mild steel of zero weld plate of dimension $500 \mathrm{~mm}$ by $175 \mathrm{~mm}$ by $25 \mathrm{~mm}$. Natural frequency of zero weld plate was found to be $51.549 \mathrm{~Hz}$, it was observed that the natural frequencies of the five joints mentioned were of close range in increasing order of $45.020 \mathrm{~Hz}, 47.949 \mathrm{~Hz}, 48.506 \mathrm{~Hz}, 49.264 \mathrm{~Hz}$ and $50.342 \mathrm{~Hz}$ for square groove butt welded joint. The natural frequency of the square groove butt welded joint was observed to be closest to the zero weld plate; therefore we recommend square groove butt weld as optimum butt weld for engineering constructions because it failed the least when compared to other types of butt joints.
\end{abstract}

Keywords: Butt Welded Joints, Finite Element Method (FEM), Fixed-Fixed Beam, Forced Vibration, Mild Steel Plates

\section{Introduction}

Achebo [1] wrote that welding is the most commonly used process for permanent joining of components and butt welding is used to join machine parts that are nearly parallel and do not overlap. Failure of welded components during their service life is attributed to many factors such as: abuse of welded component (overload), development of weld defects, poor welding method, metallurgical failure of welded joint, joint design, etc. Chavan, et al [2] elaborated extensively on factors affecting tensile strength of welded joints. Therefore, It is important, if a good welded joint service life is to be achieved, all the limiting factors listed above should be greatly minimised.

Seth [3] said that several failures occur in welded joints which include but not limited to lamellar tearing, failure due to fatigue etc. Haftirman, et al [4], and Rother and Rudolph [5] were of the opinion that Fatigue is a failure mechanism where the component fails after a period of time in service and also sees a repetitive cyclic stress.

The problem of fatigue mainly results from vibrating structures especially mechanical component which can lead to premature or catastrophic failure of parts. Due to the sharp increase in temperature during welding at weld zone, mechanical properties of parent metal close to the weld zone are altered. These alterations in mechanical properties of the welded parent metals (in the region of the weld zone) reduce the service life of the metal as a result of the loss or evaporation of some strength enhancing and volatile alloying elements. Parent metal with no weld (that is parent metal, as received from vendors in its original state) is more durable and long lasting when compared to the heat treated welded joint of the parent metal when subjected to vibration.

Achebo and Omoregie [6] attributed failure of mild steel welded components to the reduction in the strength of welded joints. However, Achebo [7] claimed that these inadequacies 
can be corrected by altering the process parameters aimed at optimizing the weld by using the Taguchi method with gray relational analysis. Achebo [7] was able to optimize the plasma arc welding (PAW) process parameters and concluded that the optimum process combinations have a better weld strength than the weld made by the existing process parameters.

Analysing weldment using Computer Aided Design (CAD) has long been in use, Masubuchi and Yada [8] were one of the pioneers in CAD analysis of weldment. Thirugnanam, el al [9] carried out a simulation using ANSYS to analyze and predict stresses in welded joints during bending and torsion, they compared the results obtained with values obtained from their analytical solution and concluded that both methods yielded approximate results. Hafti, et al [10] compared the effect of welding on dissimilar plates of stainless steel and aluminum using experimental modal analysis and FEM modal analysis CAD software, he also concluded that both methods were in good agreement. Putti and Ratnam [11] carried out a similar comparison between the experimental and analytical modal analysis (ANSYS) on welded structure used for Vibration Based Damage Identification process. Both approach yielded approximate results. However, due to the robustness of CAD sofeware, simulation of weldment of any nature can be achieved with high degree of accuracy which is expected to greatly reduce cost and stresses of repeated weld experiment.

\section{Materials and Methods}

\subsection{Materials}

In this work, modal analysis using finite element method (ANSYS 14.5) was used to analysis five types of mild steel butt weld joints and compared to the zero weld parent metal. The model consists of two plates of dimensions $250 \mathrm{~mm}$ by $175 \mathrm{~mm}$ by $25 \mathrm{~mm}$ welded at one end using single $\mathrm{v}$ groove butt weld, double v groove butt weld, single u groove butt weld, double u groove butt weld, square groove butt welded joint and a single plate of dimension $500 \mathrm{~mm}$ by $175 \mathrm{~mm}$ by $25 \mathrm{~mm}$ without weld. The geometry was modelled to be a welded beam of the above mentioned dimensions using AutoCAD Inventor and then exported to ANSYS where it was converted to a fixed-fixed beam after meshing before subjecting it to vibration using the modal analysis tool to get the natural frequencies and mode shapes of the materials.

Mechanical properties of structural steel that were used in this design study include:

(1) Modulus of elasticity, E of $2 \times 10^{11} \mathrm{~N} / \mathrm{m}^{2}$

(2) Poisson's ratio, $v$ of 0.3

(3) Density of structural steel, $\rho$ of $7850 \mathrm{~kg} / \mathrm{m}^{3}$

\subsection{Theoretical Method}

For the fixed-fixed beam subjected to free vibrational excitation, which we assumed that the beam has a distributed mass throughout the entire length. Where Length (L) is $0.5 \mathrm{~m}$, Width (b) is $0.175 \mathrm{~m}$, Thickness (h) is $0.025 \mathrm{~m}$ and the Moment of inertial for a rectangular plate (I), is presented as

$$
I=\frac{b h^{3}}{12} \mathrm{~m}^{4}
$$

The eigenvalues $(\mathrm{K})$ are expressed in Table 1.

Table 1. Eigenvalues.

\begin{tabular}{ll}
\hline $\mathbf{n}$ & K \\
\hline 1 & 4.73004 \\
2 & 7.85321 \\
3 & 10.9956 \\
4 & 14.13717 \\
5 & 17.27876 \\
\hline
\end{tabular}

Substituting values into Eq. (1), it becomes

$$
\begin{aligned}
& I=\frac{0.175 \times 0.025^{3}}{12} \\
& I=2.279 \times 10^{-7} \mathrm{~m}^{4}
\end{aligned}
$$

The natural frequency of the material is expressed in Eq. (2)

$$
f_{n}=\frac{1}{2 \pi}\left[\frac{K}{L}\right]^{2} \sqrt{\frac{E I}{\rho}}
$$

Substituting the values of $E, I$ and $\rho$ of mild steel into Eq. (2) gives

$$
f_{n}=0.3835\left[\frac{K}{L}\right]^{2}
$$

Eq. (3) can be simplified further if $L=0.5 \mathrm{~m}$ in Eq. (3) to obtain

$$
f_{n}=1.534 K^{2}
$$

$K$ is constant $=$ Eigenvalue

From the eigenvalue table given in Table 1, the values of $K$ are substituted for $n=1,2,3,4$ and 5 into Eq. (4) to get the natural frequencies $f_{1}, f_{2} \ldots$ ass follows

When, $\mathrm{n}=1$, and $K=4.73004$

$$
\begin{gathered}
f_{1}=1.534 \times 4.73004^{2} \\
f_{1}=34.321 \mathrm{~Hz}
\end{gathered}
$$

When, $\mathrm{n}=2$ and $K=7.85321$

$$
\begin{gathered}
f_{2}=1.534 \times 7.85321^{2} \\
f_{2}=94.606 \mathrm{~Hz}
\end{gathered}
$$

Following these procedures, the remaining natural frequencies for $f_{3}, f_{4}$ and so on can be calculated.

\subsection{Finite Element Analysis}

Commercial FEM software analyzes finite element problem in three steps, namely: preprocessing, solution and post processing.

(1) Preprocessing: This includes defining the geometric properties of the problem, the element types to be used, the material properties of the elements, the geometric properties of the elements (length, area etc.), the 
element connectivity (mesh the model), the physical constraints (boundary conditions) and the loadings.

(2) Solution: The features in this step such as matrix manipulation, numerical integration, and equation solving are carried out automatically by the software. The governing algebraic equation in matrix form, computation of the unknown values of the primary field and assembling is done automatically.

(3) Post processing: Interpretation and evaluation of results is expressed this stage.

Figures 1 to 6 show the basic model of the weld geometries for the various cases. AutoCAD Inventor was used for the design and exported to ANSYS. Two plates of $250 \mathrm{~mm} x$ $175 \mathrm{~mm} \times 25 \mathrm{~mm}$ were welded together using the butt welded geometries in each cases, with the last geometry modelled into a plain plate of dimension $500 \mathrm{~mm}$ by $175 \mathrm{~mm}$ by $25 \mathrm{~mm}$ without weld.

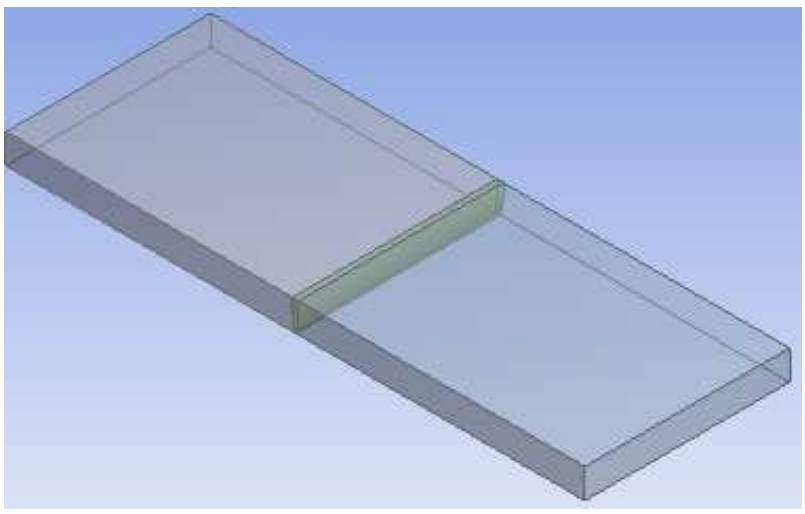

Figure 1. Single u groove butt welded joint.

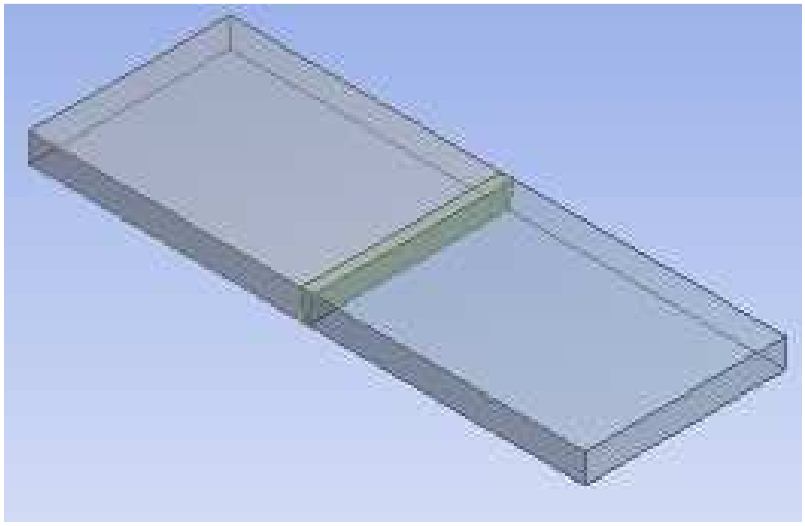

Figure 2. Single v groove butt welded joint.

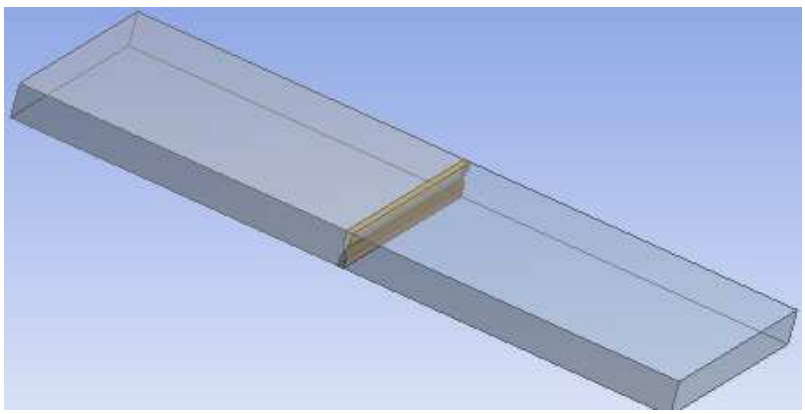

Figure 3. Double u groove butt welded joint.

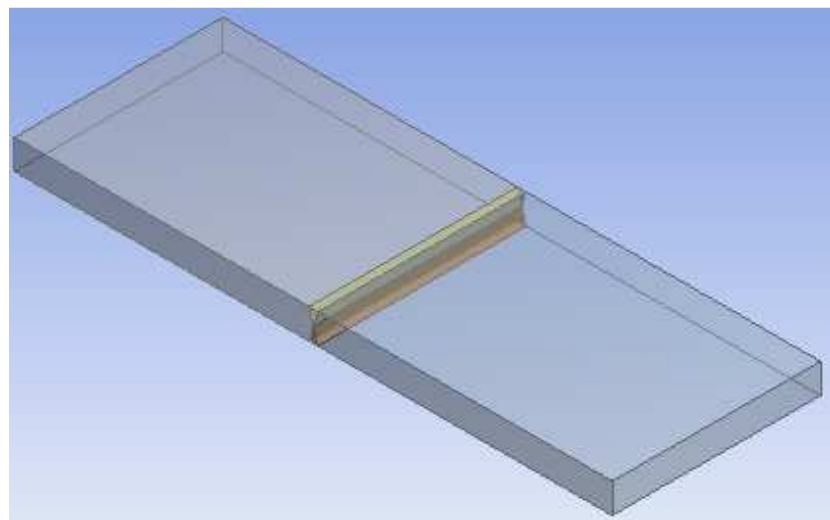

Figure 4. Double v groove butt welded joint.

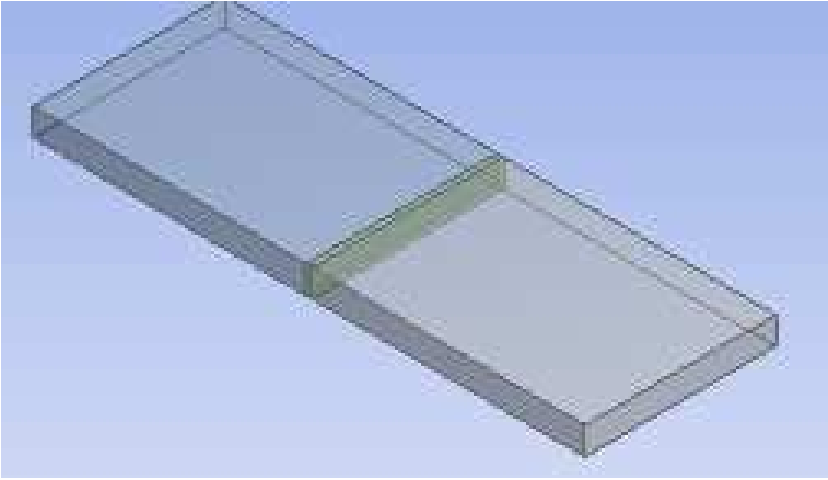

Figure 5. Square groove butt welded joint.

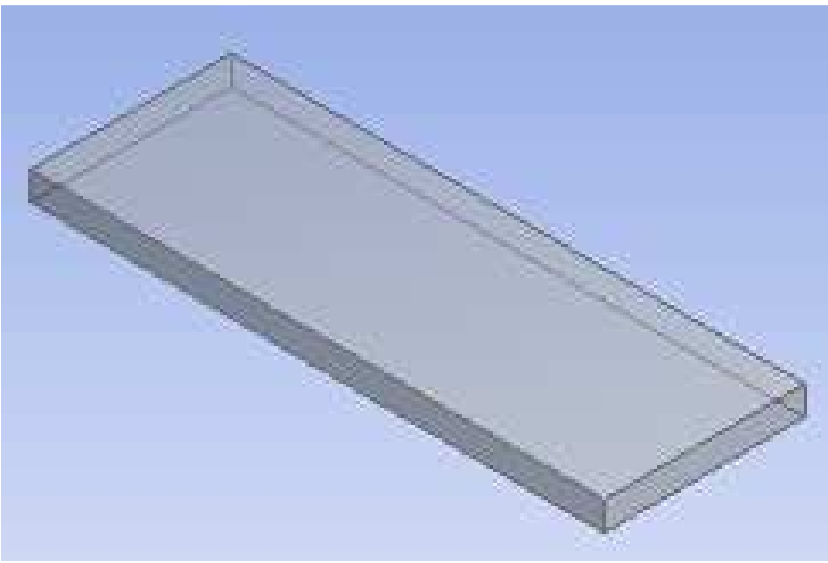

Figure 6. Plate without weld.

The surface mesh for the specimen are shown in Figures 7 to 12

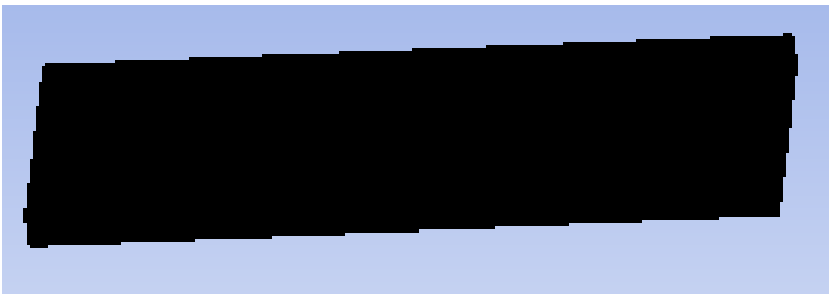

Figure 7. Surface mesh for single u groove butt welded joint. 


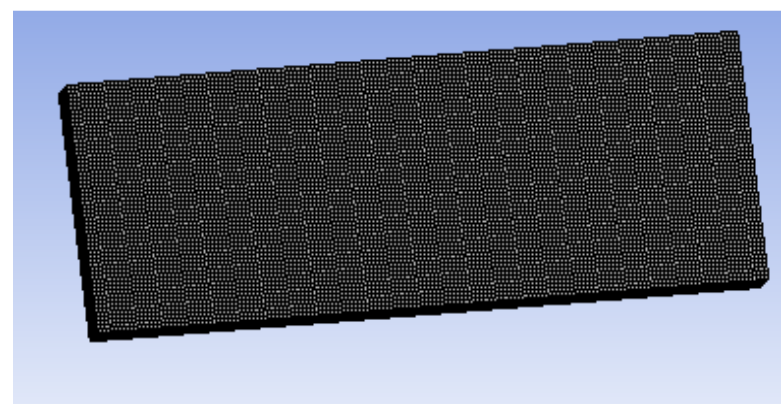

Figure 8. Surface mesh for single v groove butt welded joint.

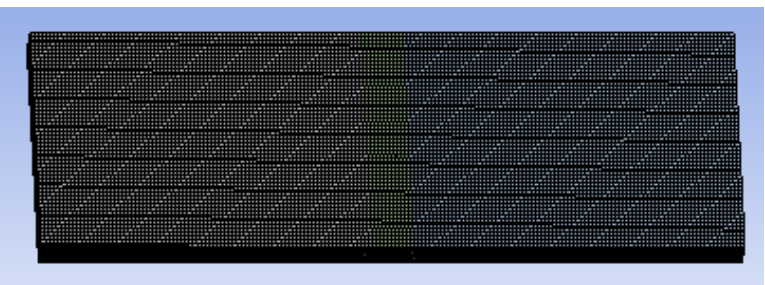

Figure 9. Surface mesh for double u groove butt welded joint.

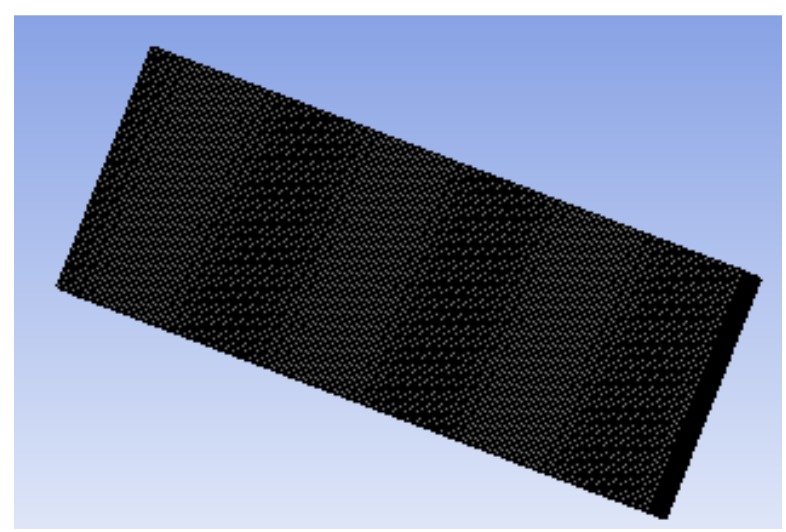

Figure 10. Surface mesh for double v groove butt welded joint.

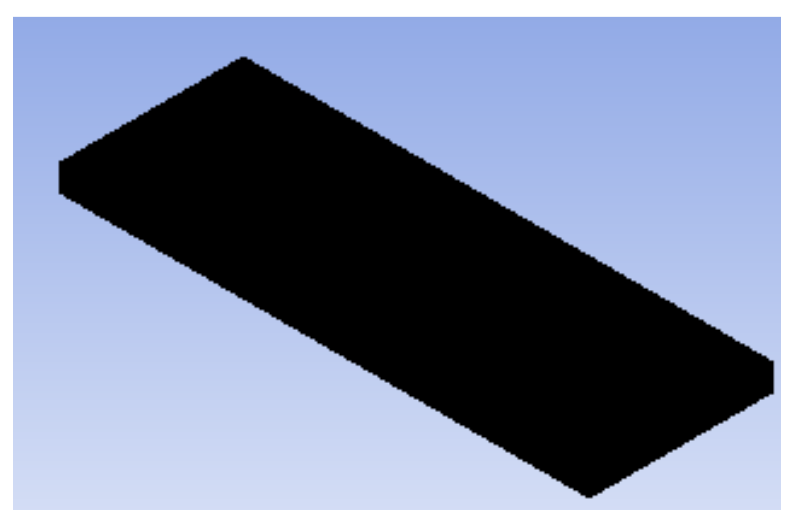

Figure 11. Surface mesh for square groove butt welded joint.

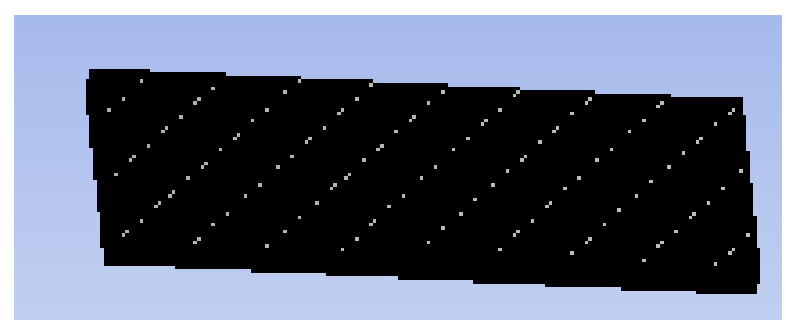

Figure 12. Surface mesh for the plate without weld.

\section{Results and Discussion}

\subsection{Grid Independent Test}

Grid independent test was carried out in order to ensure that the results do not vary with grid size. Table 2 shows the first natural frequency of single $\mathrm{v}$ groove butt welded joint, double $\mathrm{u}$ groove butt welded joint and double $\mathrm{v}$ groove butt welded joint for three different number of nodes in the discretised domains. Figures 13 to 15 show the plot of first modal frequency against number of nodes for the single $v$ groove butt welded joint, double $\mathrm{u}$ groove butt welded joint and double $\mathrm{v}$ groove butt welded joint respectively.

Table 2. Grid independent test result.

\begin{tabular}{lllllll}
\hline $\begin{array}{l}\text { Welded } \\
\text { Joint }\end{array}$ & Grid1 & Freq1 & Grid2 & Freq2 & Grid3 & Freq3 \\
\hline SingleV & 21931 & 47.949 & 40651 & 47.93 & 106961 & 47.893 \\
DoubleU & 21931 & 48506 & 45369 & 48.49 & 113853 & 48.474 \\
DoubleV & 31827 & 49.327 & 100405 & 49.277 & 419851 & 49.264 \\
\hline
\end{tabular}

From the grid independent test carried out and presented in Figure 13 to 15, it can be seen that at any grid size, the result of the first modal frequency gave a very close result. Therefore it can be concluded from the test that the results are not grid dependent.

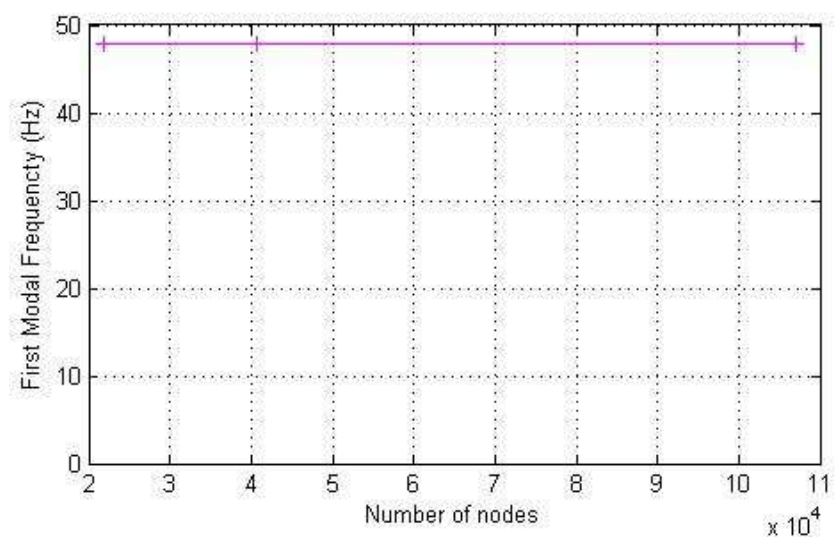

Figure 13. Grid independent test for single v groove butt welded joint.

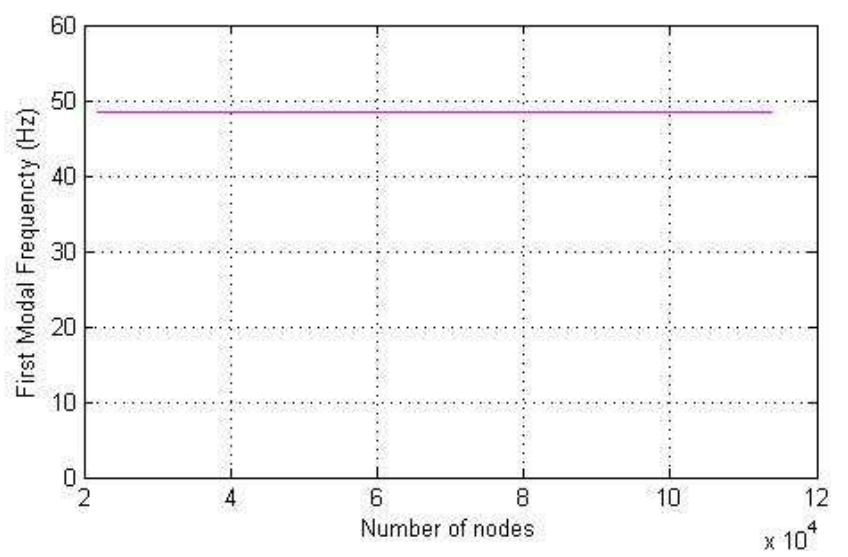

Figure 14. Grid independent test for double u groove butt welded joint. 


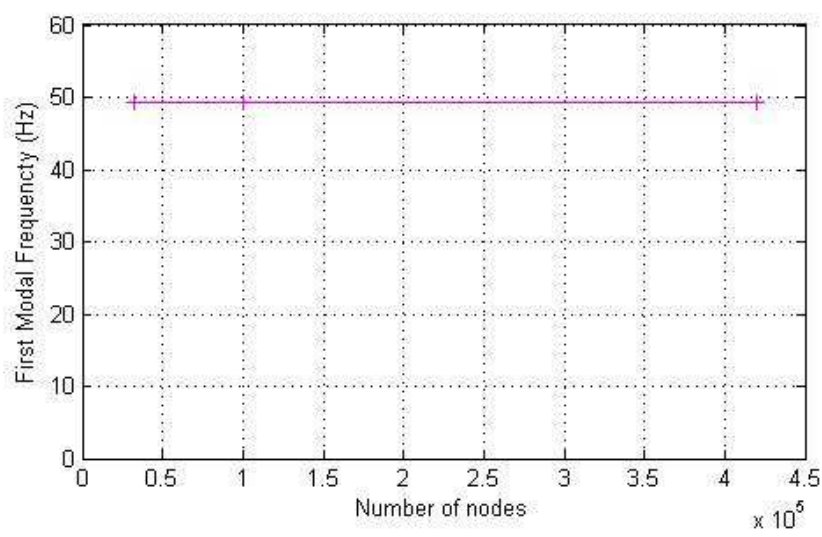

Figure 15. Grid independent test for double v groove butt welded joint.

\subsection{Mode Shapes of Five Frequencies Studied}

Presented hereunder are the results obtained from the simulations. Figures 16 to 21,22 to 27,28 to 33,34 to 39,40 to 45 show the modal shapes of the five modal frequencies studied with variation of the weld geometry (single $\mathrm{v}$ butt weld joint, double v butt weld joint, single $u$ butt weld joint, double $\mathrm{u}$ butt weld joint, square butt welded joint and a case of no weld).

Figures 16 to 45 show the mode shapes for the five butt weld geometries studied. The result show that the natural frequencies of all the welded joints are almost close to each other. The zero weld plate has higher natural frequency as expected compared with the welded plates. For the five natural frequencies studied, it can be seen that it increase from the single $\mathrm{u}$ butt weld geometry, to the single $\mathrm{v}$ butt weld geometry, to the double $u$ and $v$ butt weld geometries and then finally the square butt welded geometries.

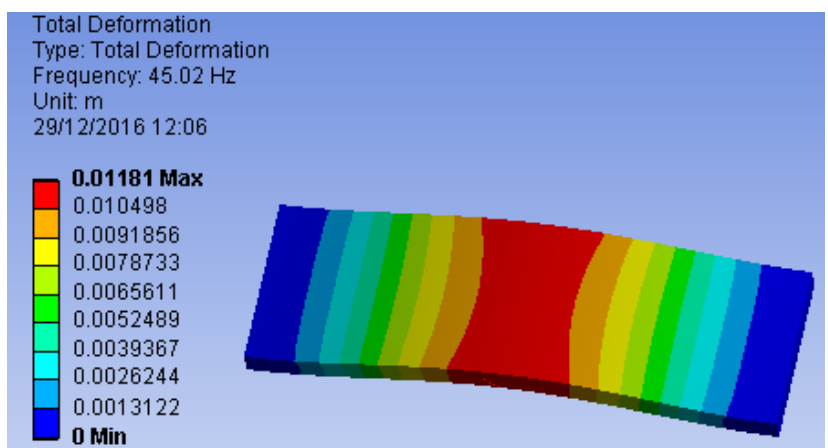

Figure 16. First Modal shape for a single U groove butt weld.

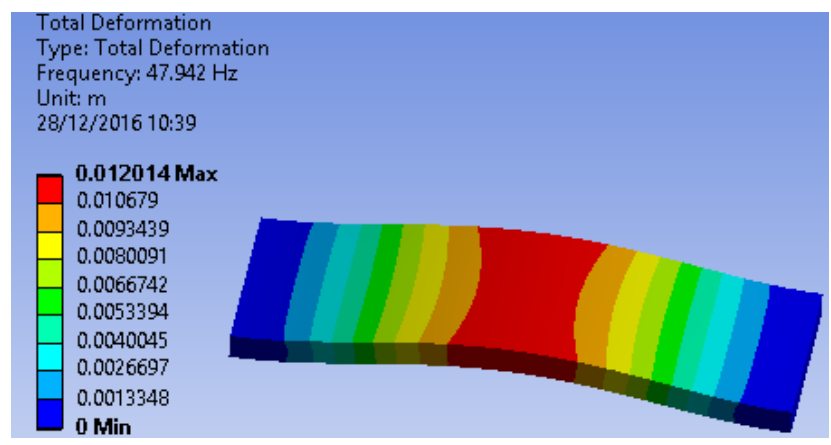

Figure 17. First Modal shape for a single V groove butt weld.

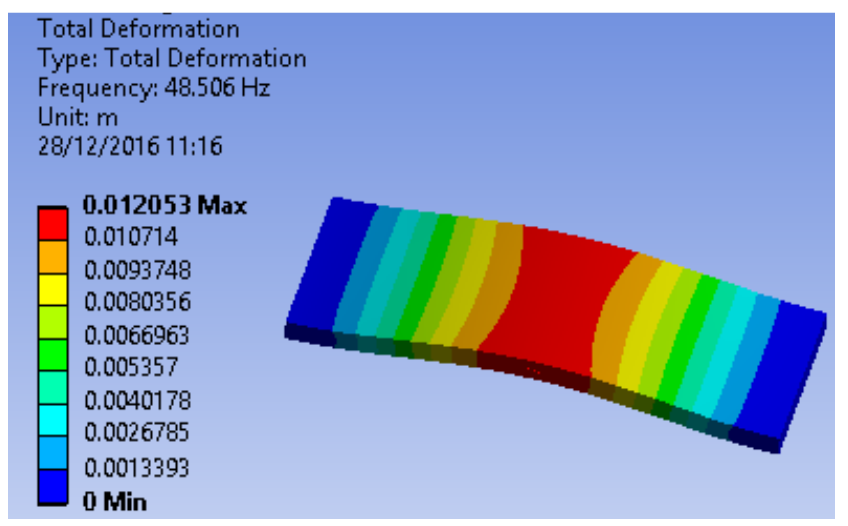

Figure 18. First Modal shape for a double U groove butt weld.

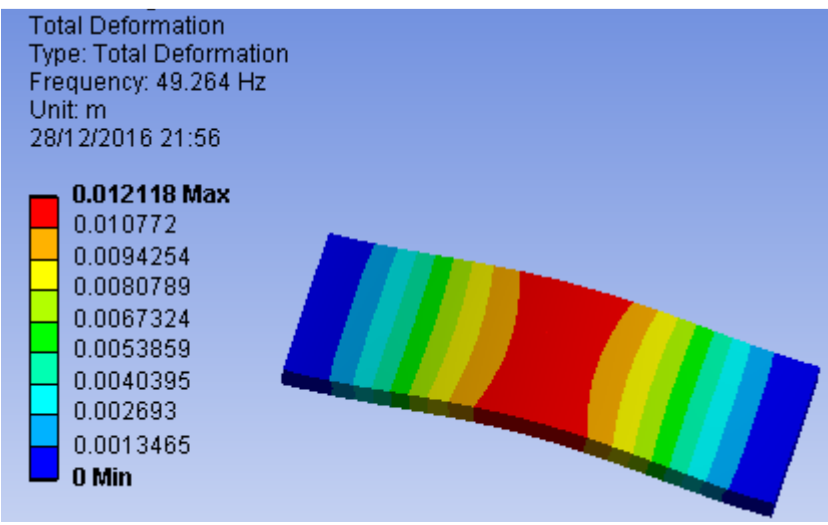

Figure 19. First Modal shape for a double V groove butt weld.

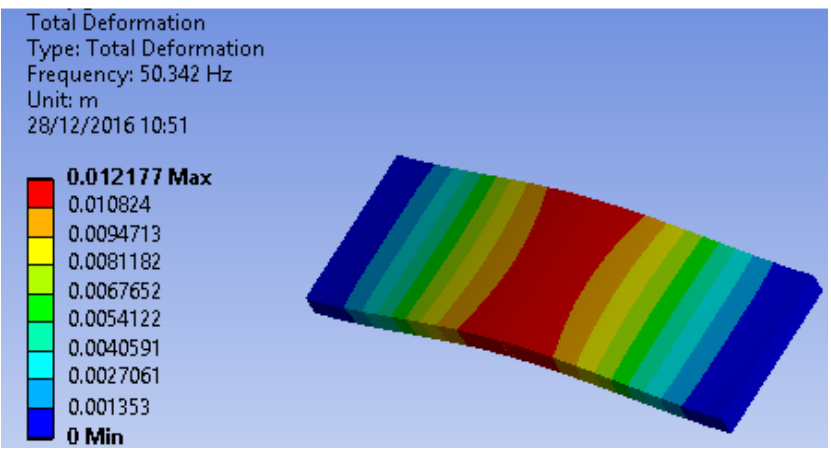

Figure 20. First Modal shape for a square groove butt weld.

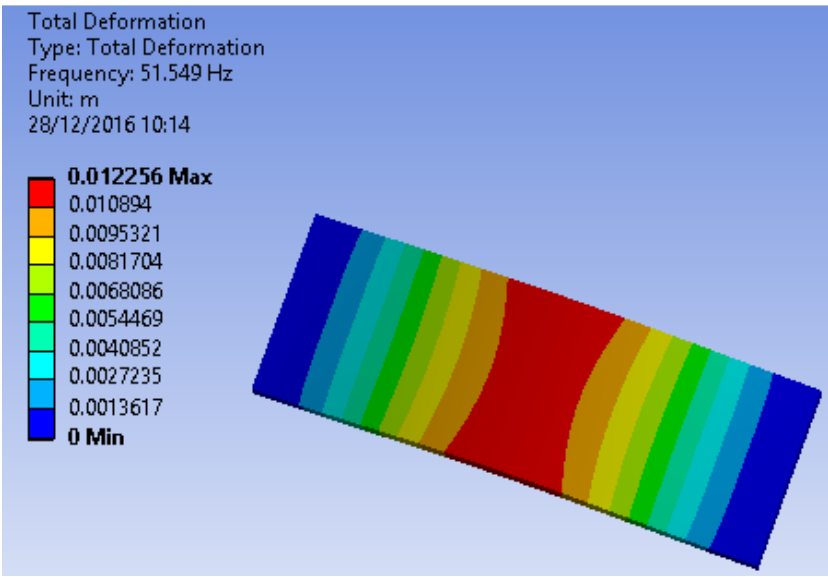

Figure 21. First Modal shape for a case of no welded joint. 


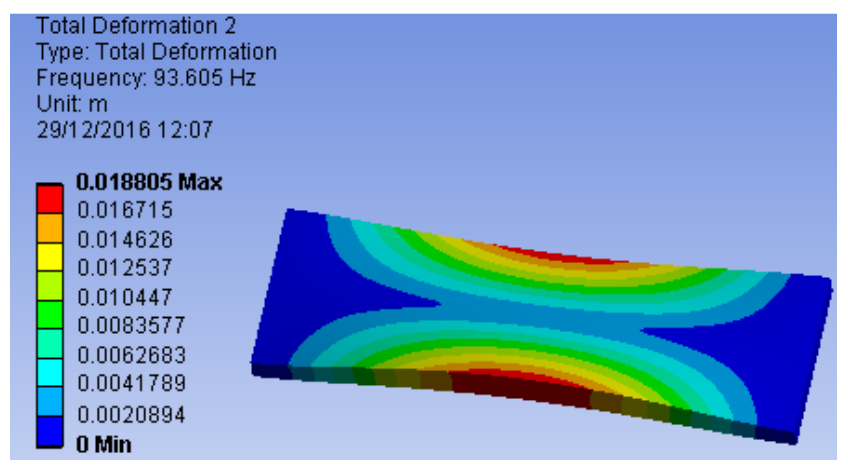

Figure 22. Second Modal shape for a single U groove butt weld.

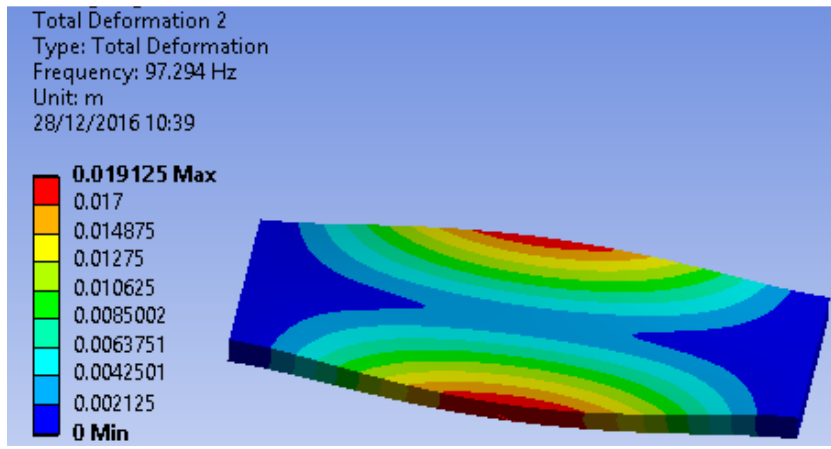

Figure 23. Second Modal shape for a single V groove butt weld.

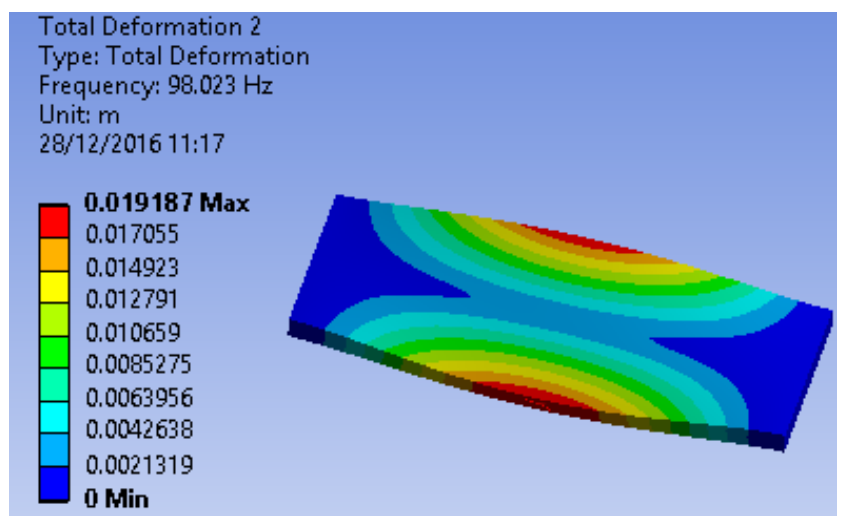

Figure 24. Second Modal shape for a double U groove butt weld.

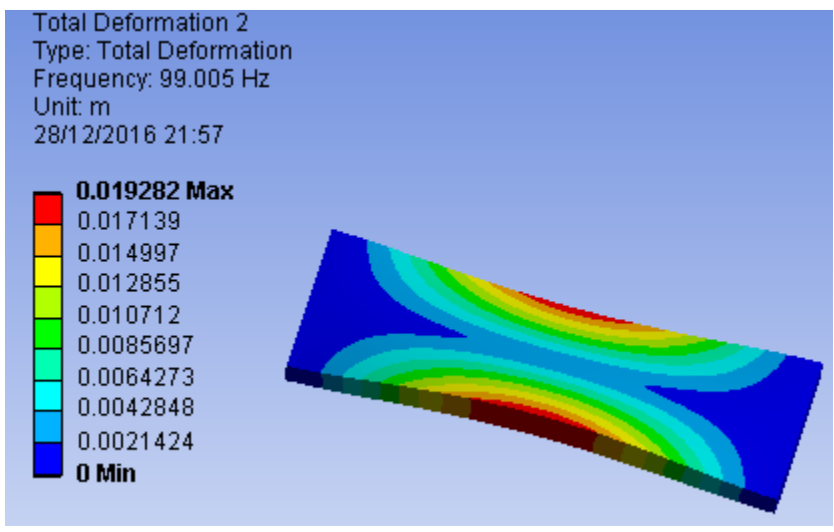

Figure 25. Second Modal shape for a double V groove butt weld.

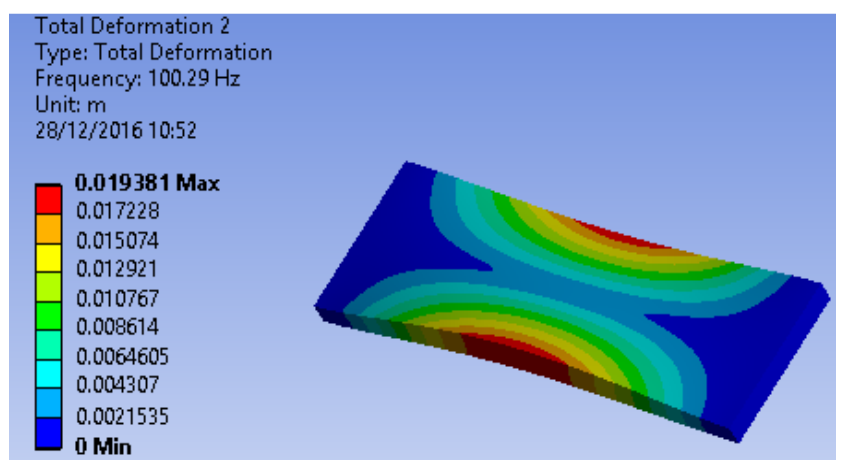

Figure 26. Second Modal shape for a square groove butt weld.

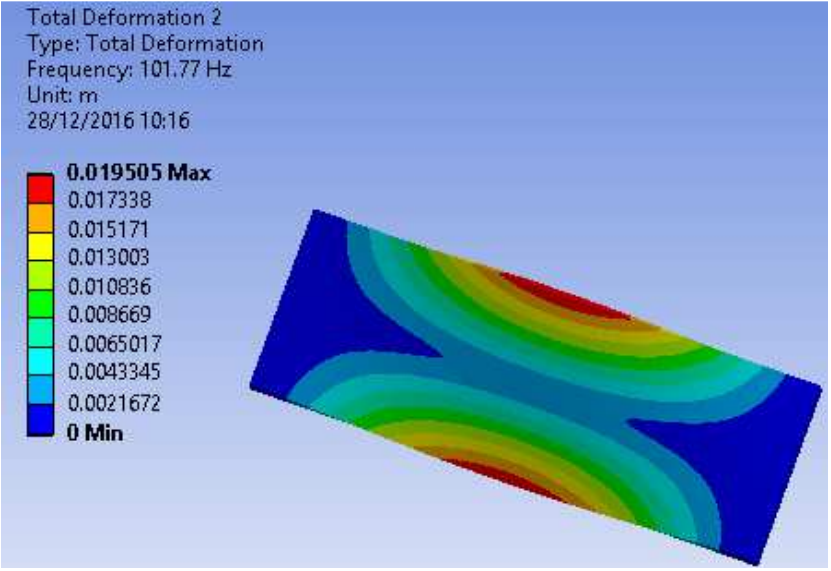

Figure 27. Second Modal shape for a case of no welded joint.

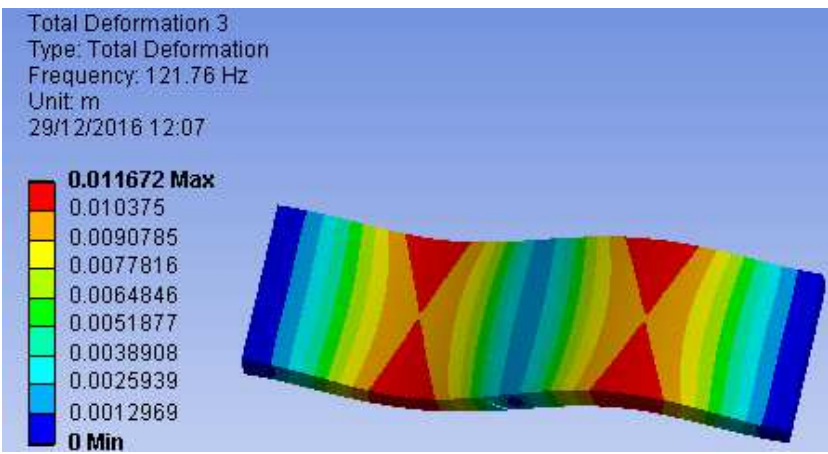

Figure 28. Third Modal shape for a single U groove butt weld.

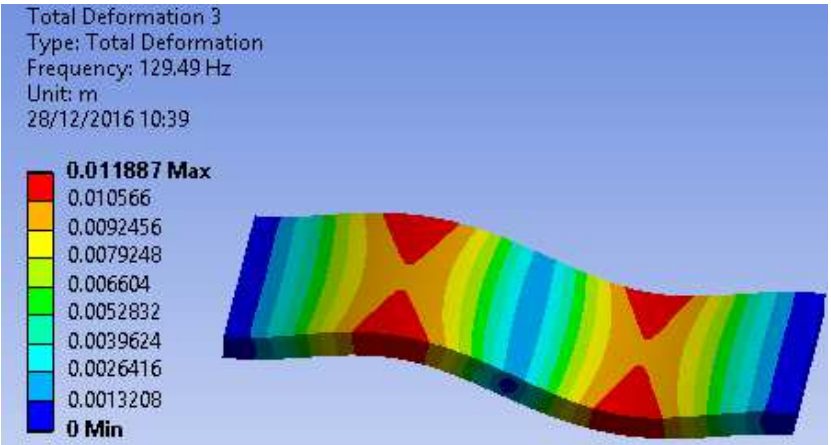

Figure 29. Third Modal shape for a single V groove butt weld. 


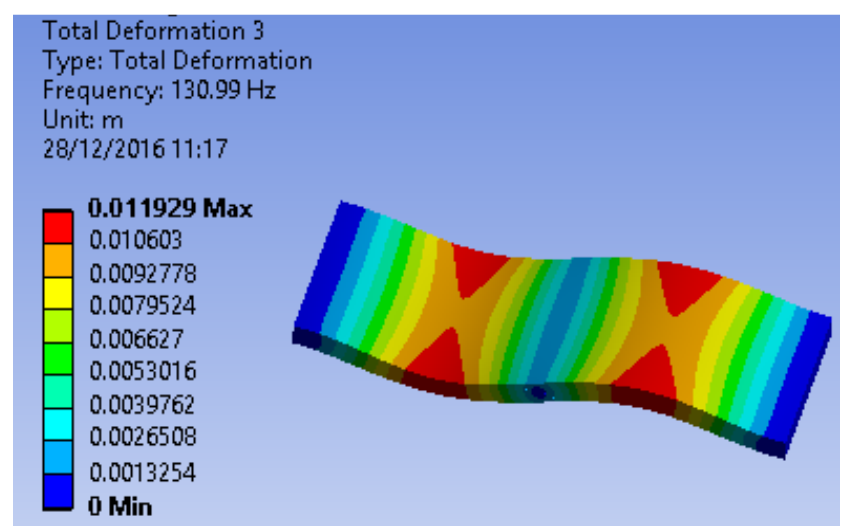

Figure 30. Third Modal shape for a double U groove butt weld.

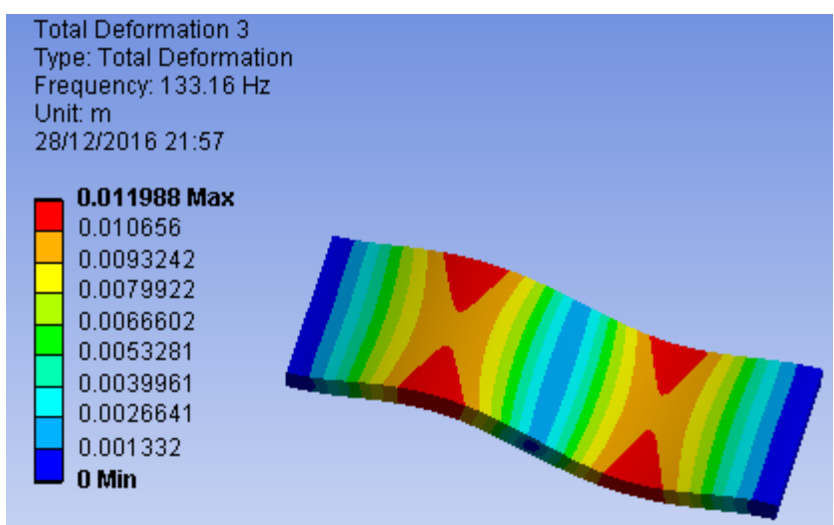

Figure 31. Third Modal shape for a double V groove butt weld.

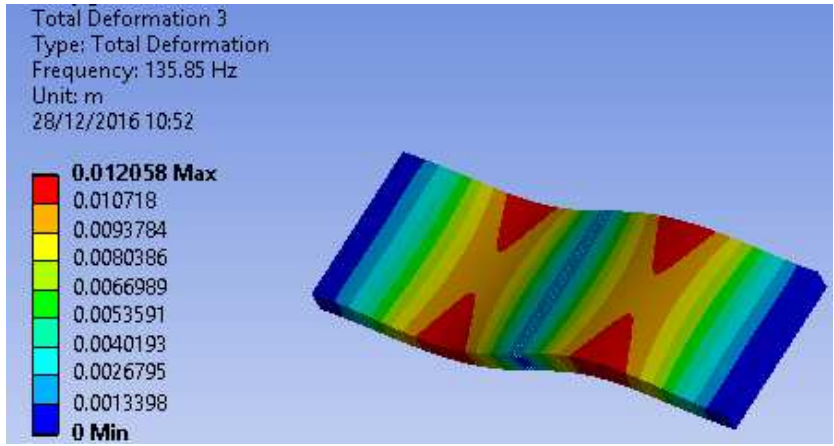

Figure 32. Third Modal shape for a square groove butt weld.

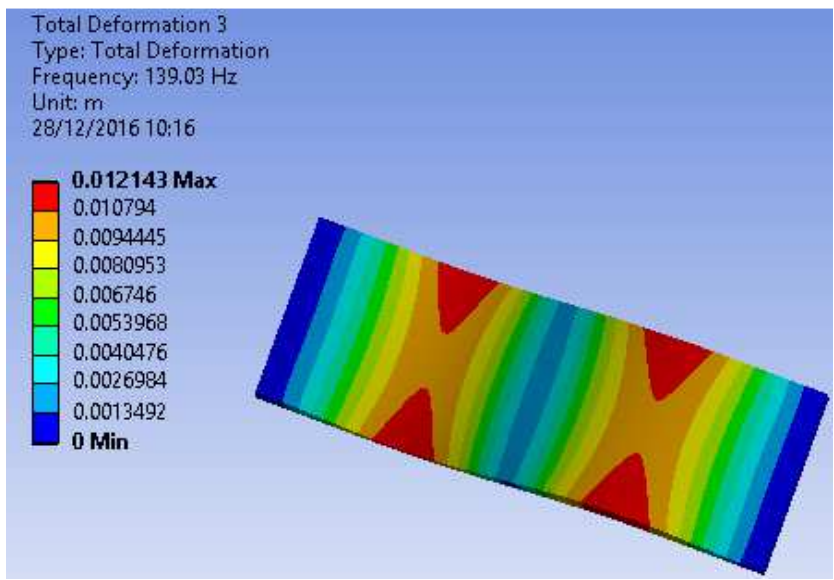

Figure 33. Third Modal shape for a case of no welded joint.

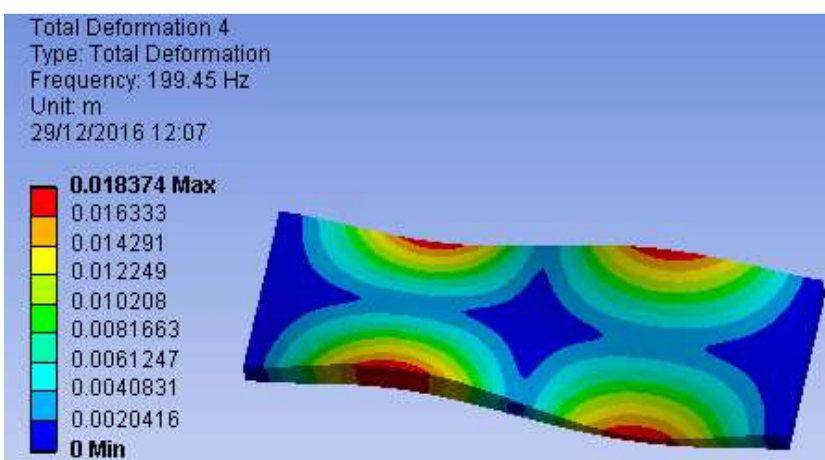

Figure 34. Forth Modal shape for a single U groove butt weld.

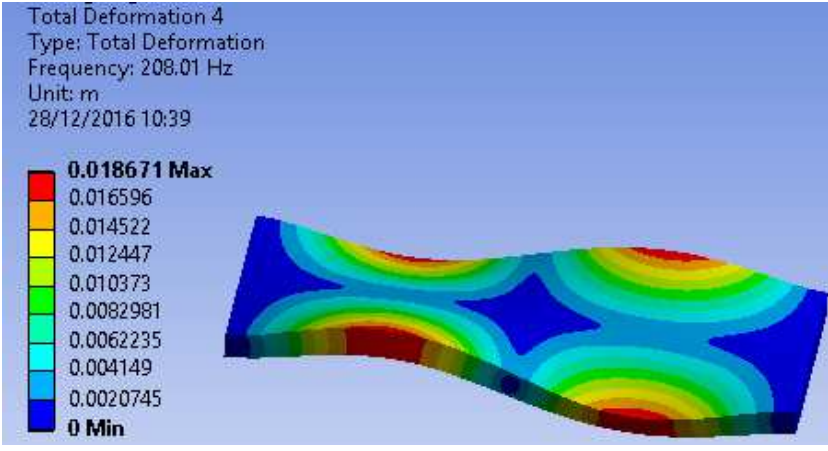

Figure 35. Forth Modal shape for a single V groove butt weld.

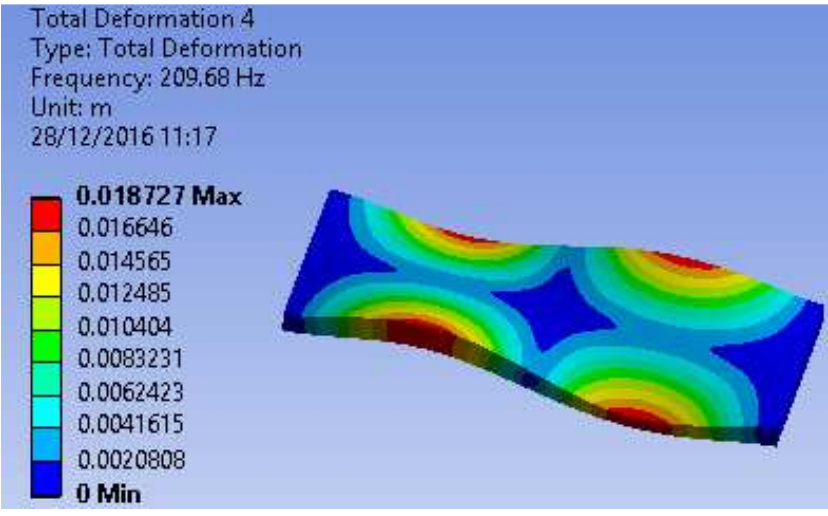

Figure 36. Forth Modal shape for a double U groove butt weld.

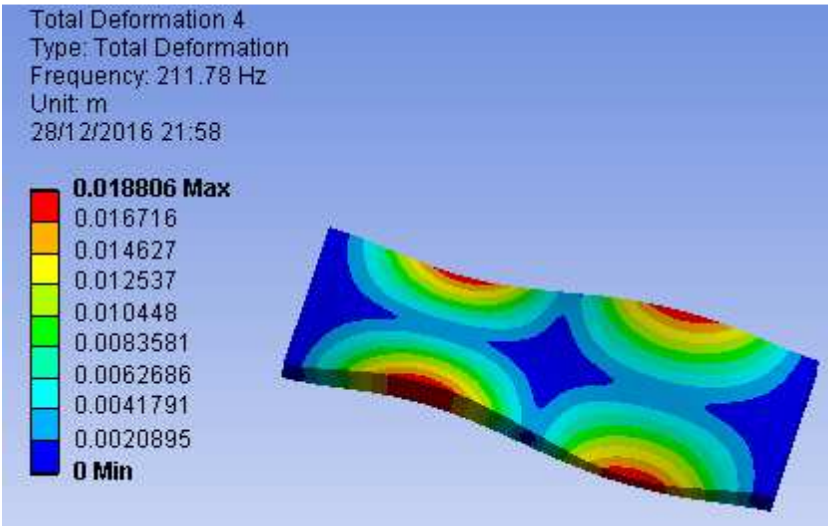

Figure 37. Forth Modal shape for a double V groove butt weld. 


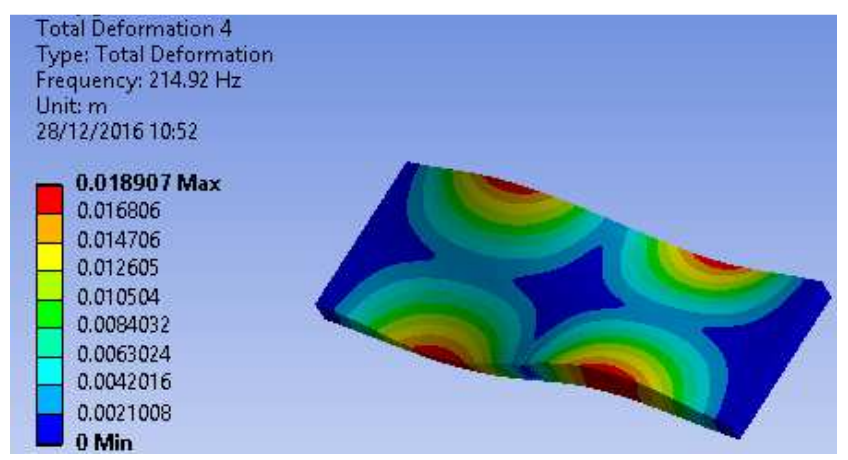

Figure 38. Forth Modal shape for a square groove butt weld.

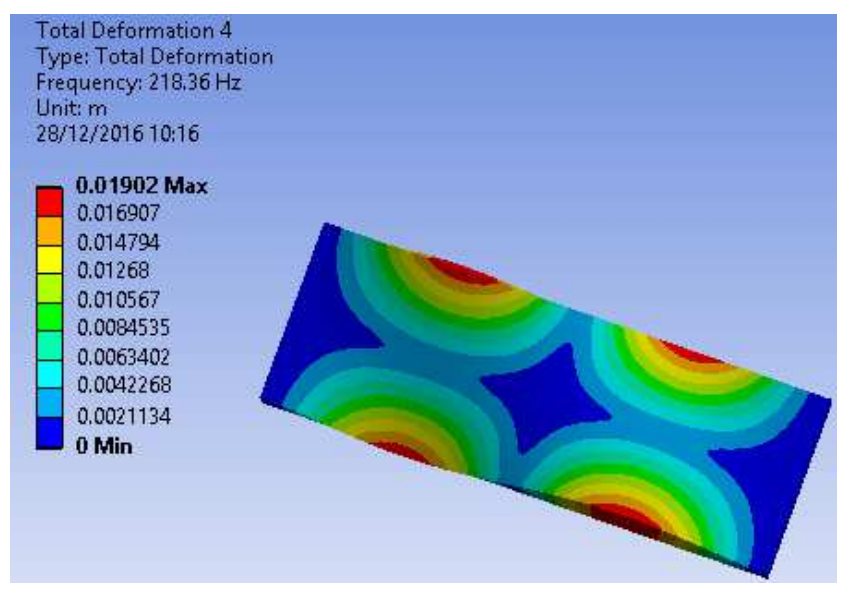

Figure 39. Forth Modal shape for a case of no welded joint.

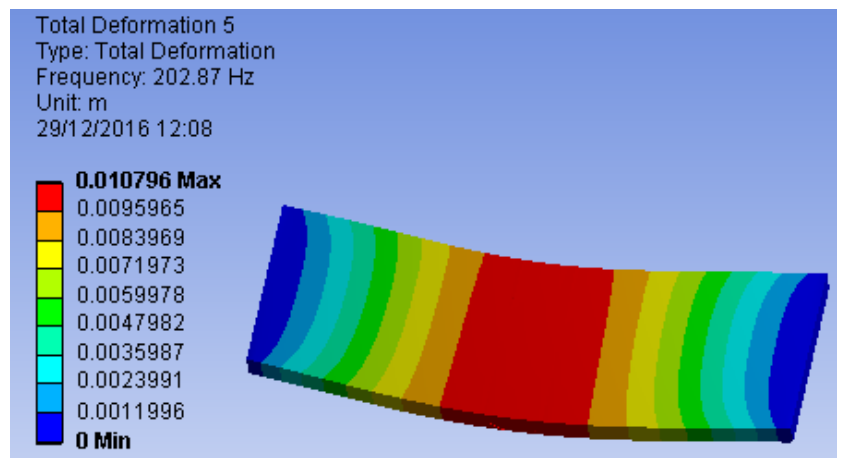

Figure 40. Fifth Modal shape for a single U groove butt weld.

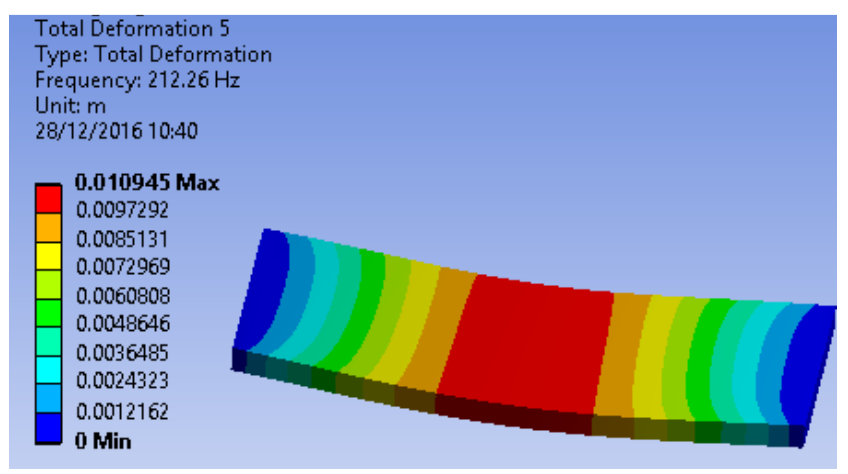

Figure 41. Fifth Modal shape for a single V groove butt weld.

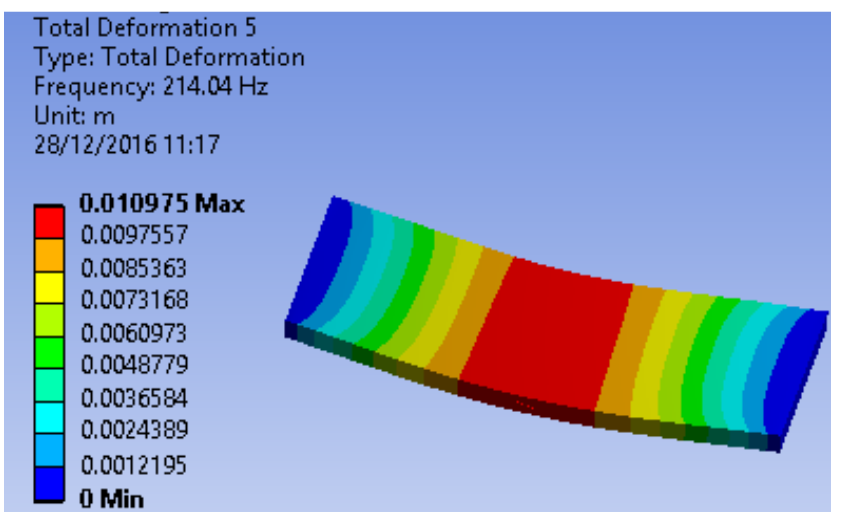

Figure 42. Fifth Modal shape for a double U groove butt weld.

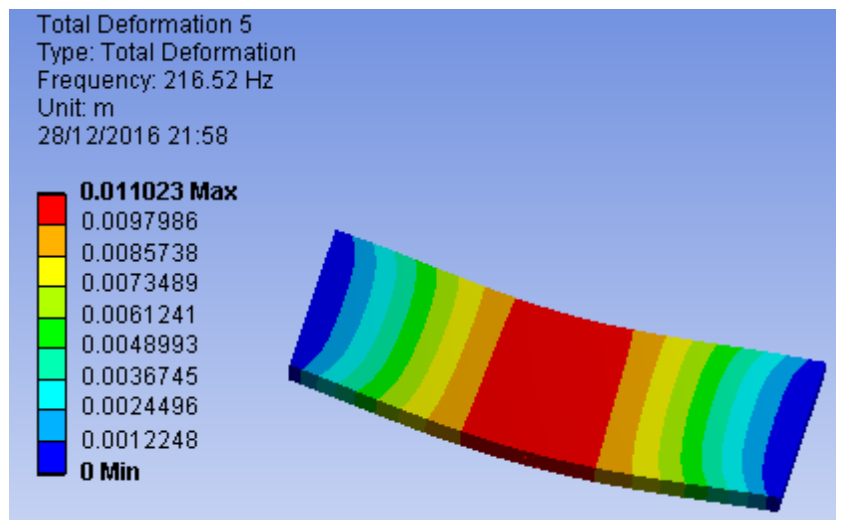

Figure 43. Fifth Modal shape for a double V groove butt weld.

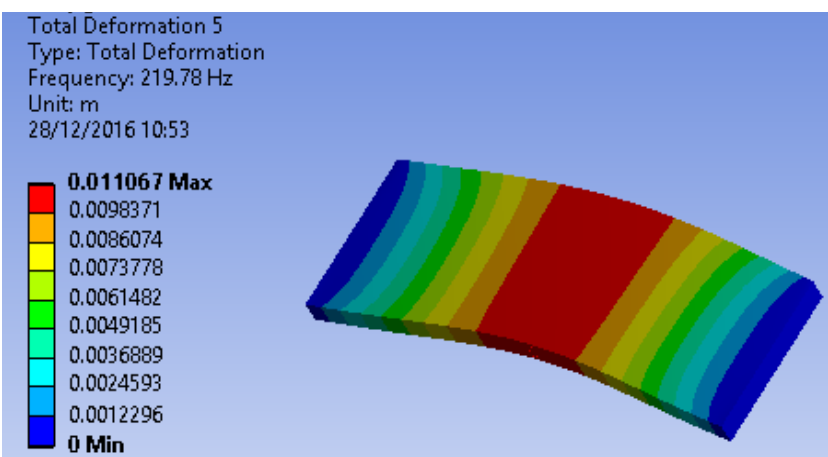

Figure 44. Fifth Modal shape for a square groove butt weld.

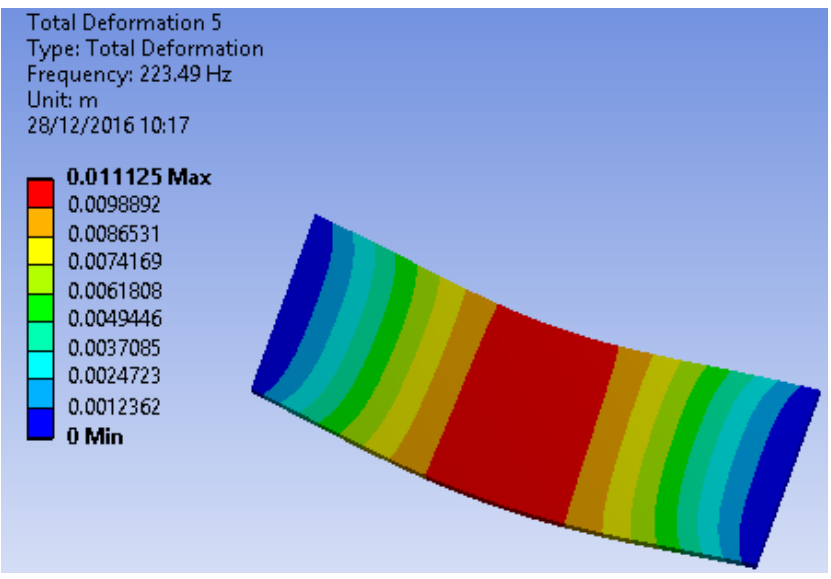

Figure 45. Fifth Modal shape for a case of no welded joint. 


\subsection{Modal Frequencies}

Table 3 shows the modal frequencies of the two plates welded using single $\mathrm{v}$ groove butt weld, double $\mathrm{v}$ groove butt weld, single u groove butt weld, double u groove butt weld, square groove butt weld and a case of no weld. Figure 9 shows the plot of the five modal frequencies against the mode shape number. It can be clearly seen from the plot that the single rectangular plate had the highest natural frequency followed by the square groove butt welded joint and then the double $\mathrm{v}$ butt welded joint. The single u groove butt welded joint was observed to have the least natural frequency for the five natural frequencies studied.

Table 3. Modal frequencies with variation of butt weld geometry.

\begin{tabular}{lllllll}
\hline Freq. Hz & $\begin{array}{l}\text { single U-groove-butt } \\
\text { welded joint }\end{array}$ & $\begin{array}{l}\text { Single V-groove-butt } \\
\text { welded joint }\end{array}$ & $\begin{array}{l}\text { double U-groove-butt } \\
\text { welded joint }\end{array}$ & $\begin{array}{l}\text { double V-groove-butt } \\
\text { welded joint }\end{array}$ & $\begin{array}{l}\text { Square Groove } \\
\text { butt welded joint }\end{array}$ & $\begin{array}{l}\text { Without } \\
\text { Welding }\end{array}$ \\
\hline First & 45.020 & 47.949 & 48.506 & 49.264 & 50.342 & 51.549 \\
Second & 93.605 & 97.294 & 98.023 & 99.005 & 100.29 & 101.77 \\
Third & 121.760 & 129.49 & 130.99 & 133.16 & 135.85 & 139.03 \\
Forth & 199.450 & 208.01 & 209.68 & 211.78 & 214.92 & 218.36 \\
Fifth & 202.870 & 212.26 & 214.04 & 216.52 & 219.78 & 223.49 \\
\hline
\end{tabular}

\subsection{Results Validation}

The simulated result was compared with the work carried out by Bhusnar and Sarawade [12]. A similar geometry found in [12] was modelled using the same material properties (Aluminium alloy) and conditions. The modal frequencies obtained were satisfactory. Figures 47 and 48 show a comparism of the first mode shape of the simulation result by [12] and also the first mode shape result obtained from this study.

The theoretical solution obtained from FEM software were compared and it was found that the difference in natural frequencies were within acceptance limits as shown in Table 4. Table 5 shows the difference in theoretical and FEM results obtained by [12].

Table 4. Modal frequencies comparison for theoretical and software Analysis.

\begin{tabular}{lll}
\hline Natural Frequencies & Theoretical Analysis & Software Analysis \\
\hline First & 34.321 & 51.549 \\
Second & 94.606 & 101.77 \\
Third & 185.466 & 139.03 \\
Fourth & 306.585 & 218.36 \\
\hline
\end{tabular}

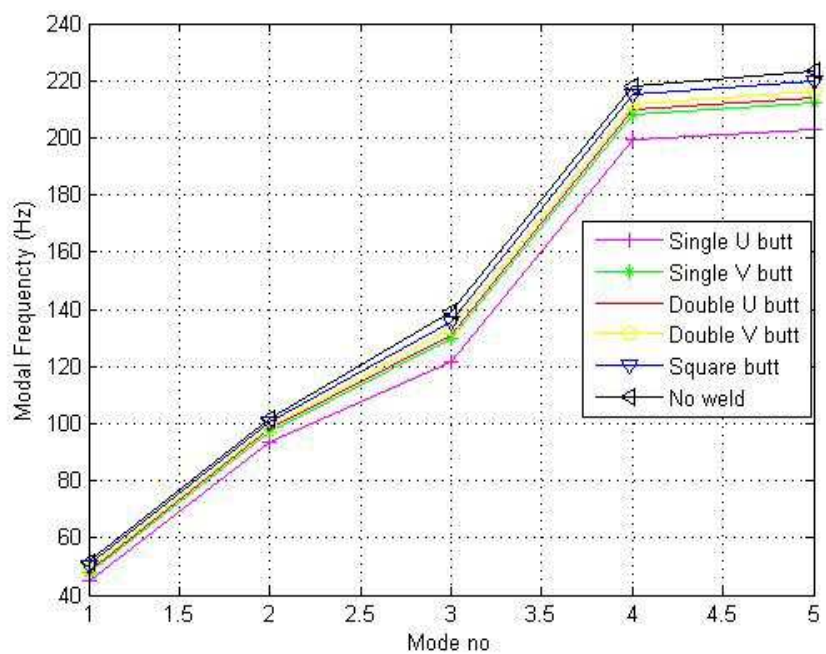

Figure 46. Plot of the modal frequencies of the various mode shapes.

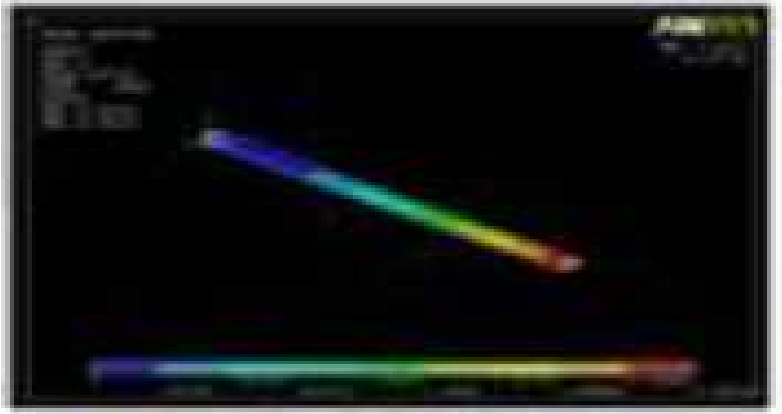

Figure 47. First mode shape adopted from [12].

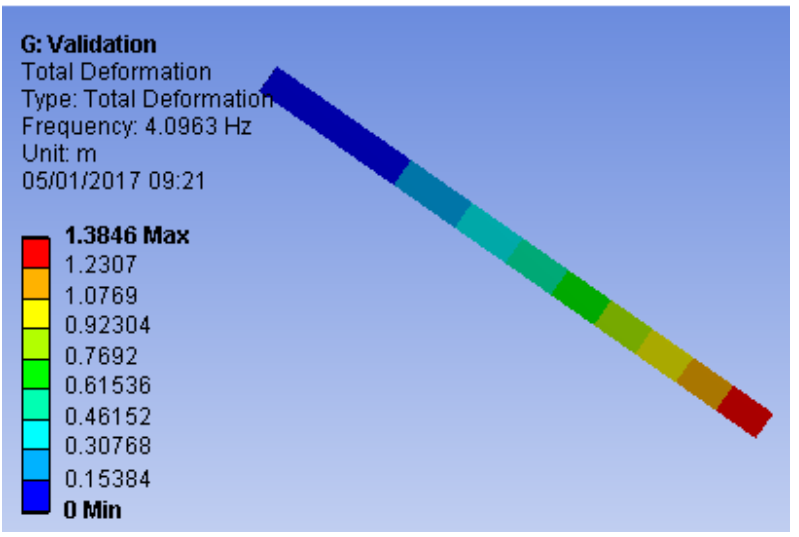

Figure 48. First mode shape from the present study.

Table 5. Modal frequencies comparison for theoretical and software Analysis from [5].

\begin{tabular}{lll}
\hline Mode Shapes & Theoretical Analysis & Software Analysis \\
\hline First & 0.130 & 0.29774 \\
Second & 0.815 & 1.3296 \\
Third & 2.108 & 1.8632 \\
Fourth & 4.471 & 5.2034 \\
\hline
\end{tabular}

\section{Conclusion}

In this work the modal analysis of various butt weld geometries and rectangular plate were done using Finite Element Analysis (FEA). Five modal shapes were studied with variation of the weld geometry; single v groove butt weld, 
double $\mathrm{v}$ groove butt weld, single u groove butt weld, double $\mathrm{u}$ groove butt weld, square groove butt welded joint and a case of no weld. The two plates were welded using the above weld geometries for each case. The specimens are made of mild steel. The analysis was carried out using modal modules of ANSYS 14.5 to get the modal analysis of the welded structures. The main objective of this work is to determine the natural frequency and mode shape of all five specimens of the welded plates fixed at both end and to compare the result of all joints with the single rectangular plate. From this study, it is found that welding process using a square groove butt weld has higher natural frequency when compared to other weld geometries. This imply that the other weld geometries will fail first and it is therefore recommended to weld using a square groove butt weld joint geometry as it exhibit more dynamic strength.

Numerical finite element analysis was carried out in this project to determine the dynamic behaviour of different butt weld groove geometries that can be applied in the welding of mild steel plates together. However, this analysis can be extended to other metallic materials. Also experimental work can be carried out to further validate the result obtained.

\section{References}

[1] Achebo, J. I. "Optimization of GMAW Protocols and Parameters for Improving Weld Strength Quality". delivered at the 2011 World Congress on Engineering: International Conference of Manufacturing Engineering and Engineering Management, Imperial College, London, July 6 - 7, 2011.

[2] Chavan, V. V, Deshpande, S. V and Valsange P. S (2016) "Tessile Strength Analysis of Lap Welded Joint of Similar Plates with F. E. A" ISSN: 2394-3696++.

[3] Seth M. Moyer, BAE/MAE." Lamellar Tearing Overview and Failures Cases". Welding Canada, 1996.
[4] Haftirman, Syayuthi, A. A. R, Afendi M. 1, Abdul Majid M. S. 1 and Tee Chin Rong "Fatigue Behavior of Butt Welded Joints in a Mild Steel". Int Conf on Marine Technology Kuala Terengganu, Malaysia, 2012.

[5] Rother K, Rudolph J, 'Fatigue assessment of welded structures: practical aspects for stress analysis and fatigue assessment', Fatigue \& Fracture of Engineering Materials \& Structures, 2011, vol. 34, no. 3, pp. 177-204, $<\mathrm{http} / / / \mathrm{dx}$. doi.org/10.1111/j.1460-2695.2010.01506.x>.

[6] Joseph Achebo, Monday Omoregie (2015) "Application of Multi-Criteria Decision Making Optimization Tool for Determining Mild Steel Weld Properties and Process Parameters Using the TOPSIS" ISSN: 2327-2635 (Print); ISSN: 2327-2643.

[7] J. I. Achebo (2012) "Effect of Multi-Response Performance Characteristics on Optimum Plasma Arc Welding Process Parameters" ISSN 1115-8443.

[8] K. Masubuchi, and T. Yada, "Use of Computers in Welding Fabrication." International Conference on Computer Applications in the Automation of Shipyard Operation and Ship Design, Tokyo, Japan, August 28-30, 1973.

[9] Thirugnanam A, Manish kumar and Lenin Rakesh (2014). Analysis of Stress in Welded Joint in Bending and in Torsion Using 'Ansys. Middle-East Journal of Scientific Research 20 (5): 580-585, 2014.

[10] Hatifi MM, Firdaus MH, Razlan AY. Modal analysis of dissimilar plate metal joining with different thicknesses using MIG welding. Int J Automotive Mech Eng 2014; 9: 17231733.

[11] Putti Srinivasa Rao, Ch. Ratnam (2012) "Experimental and Analytical Modal Analysis of Welded Structure Used For Vibration Based Damage Identification" ISSN: 2249-4596.

[12] Bhusnar M, S. S. Sarawade (2016). Modal Analysis of Rectangular Plate with Lap Joints to Find Natural Frequencies and Mode Shapes. IOSR Journal of Mechanical \& Civil Engineering (IOSRJMCE). 